\title{
PENGARUH SUPLEMANTASI VITAMIN C DIBANDINGKAN DENGAN MULTI VITAMIN- MINERAL TERHADAP STATUS ZAT GIZI ANTIOKSIDAN PADA WANITA PEKERJA
}

\author{
Fitrah Ernawati'; Rimbawan²; Hadi Riyadi'; I.Wayan T.Wibawan' ${ }^{2}$ dan Muhilal ${ }^{3}$ \\ ${ }^{1}$ Mahasiswa S3 Program Studi IImu Gizi Masyarakat, Fakultas Ekologi Manusia, IPB \\ ${ }^{2}$ Pengajar Departemen Gizi Masyarakat, Fakultas Ekologi Manusia, IPB \\ ${ }^{3}$ Mantan Anggota Dewan Riset Nasional
}

\section{ABSTRACT
EFFECT OF THE VITAMIN C SUPLEMENTATION TOWARD MULTI VITAMIN-MINERAL ON THE STATUS OF NUTRITIONAL ANTIOXIDANT IN WOMAN WORKERS

Micronutrients, both vitamins and minerals are needed by the body in limited quantities, but their role is essential to the body. To fulfill vitamin and mineral requirements, consumption of variant and balanced diet is needed because most vitamins and minerals are not produced by our body. Food supplements can be a good alternative in providing sufficient amount of micronutrient if intake from dietary sources are not enough. This research was intended to analyse the effect of multi vitaminmineral (MVM) supplementation compared to a single nutrient supplementation (Vit C $1000 \mathrm{mg}$ ) on dietary antioxidant status. It was conducted on Februari 2008 and the design of this research was a double blind randomized controlled trial. There were 92 samples aged 20-45 years old, healthy (physically and clinically), did not consume alcohol, did not smoke and were willing to partipate in the research. Multi vitamin-mineral supplementation increased serum concentration of vitamin $E$ and superoxide dismutase (SOD) significantly $(p<0.05)$, while single supplementation of vitamin C $1000 \mathrm{mg}$ improved only vitamin $\mathrm{C}$ status. Suplementation of multi vitamin-mineral reduced free radicals by improving superoxide dismutase (SOD) status.

Keywords: multi vitamin-mineral supplementation, superdioxide dismutase status, vitamin $\mathrm{E}$ status, vitamin $\mathrm{C}$ status.

\section{PENDAHULUAN}

Z

at gizi mikro, baik vitamin maupun mineral diperlukan oleh tubuh dalam jumlah terbatas, namun mempunyai peranan yang sangat penting. Kekurangan zat gizi mikro pada tingkat ringan sekalipun dapat mempengaruhi produktivitas kerja, dan kualitas sumber daya manusia'. Zat gizi mikro selain berfungsi di dalam membantu kerja berbagai jenis enzim juga beberapa diantaranya bersifat antioksidan.

Antioksidan mempunyai peranan yang besar dalam melindungi tubuh dari radikal bebas. Radikal bebas merupakan salah satu bentuk senyawa oksigen reaktif, yang secara umum diketahui sebagai senyawa yang memiliki elektron yang tidak berpasangan. Radikal bebas dapat terbentuk ketika metabolisme normal berlangsung, misalnya ketika komponen makanan diubah menjadi bentuk energi. Pada proses metabolisme tersebut sering terjadi kebocoran elektron yang mudah sekali terbentuk radikal bebas seperti anion superoksida, hidroksil ${ }^{2,3}$. Zat pengoksidan atau radikal bebas lain juga dapat berasal dari luar tubuh misalnya asap rokok, asap mobil, polutan dll.

Tubuh memerlukan zat gizi mikro termasuk vitamin dan mineral yang bersifat antioksidan dalam jumlah yang cukup. Sementara itu seluruh mineral dan sebagian besar vitamin tidak dapat disintesa oleh tubuh, sehingga untuk memenuhi kebutuhan vitamin dan mineral diperlukan konsumsi makanan yang seimbang dan beragam. Dalam kondisi tertentu, dimana vitamin dan mineral yang bersumber dari makanan tidak dapat memenuhi kebutuhan, maka suplemen zat gizi dapat digunakan sebagai alternatif pilihan. Meskipun demikian dalam International Conference on Nutrition Tahun 1992, FAO/WHO menyatakan bahwa 
suplementasi zat gizi lebih diprioritaskan untuk kelompok rawan (vulnerable group) yang tidak dapat memenuhi kebutuhannya akan zat gizi melalui makanan, seperti bayi dan anak-anak, lansia, kelompok dengan sosial ekonomi rendah, orang terlantar, pengungsi, penduduk yang berada dalam kondisi darurat, dan wanita usia subur (WUS) ${ }^{4}$.

Secara umum antioksidan dikelompokkan menjadi 2 yaitu antioksidan enzimatis dan non-enzimatis. Antioksidan non-enzimatis adalah zat gizi antioksidan seperti $\beta$-karoten, vitamin $E$, vitamin $C$. Sementara itu antioksidan enzimatis antara lain glutation peroksidase (GSH-Px), superoksida dismutase (SOD), dan katalase, dimana untuk aktifitasnya memerlukan zat gizi seperti $\mathrm{Cu}$, zinc dan $\mathrm{Fe}^{5}$. Vitamin $\mathrm{C}$ merupakan salah satu zat gizi mikro yang bersifat antioksidan yang sudah dikenal luas oleh masyarakat dan terus diteliti lebih dari 30 tahun $^{6}$. Vitamin C dikenal sebagai antioksidan karena kemampuan vitamin $\mathrm{C}$ sebagai elektron donor sehingga mampu merubah senyawa radikal bebas menjadi tidak berbahaya ${ }^{2}$. Stress oksidatif terjadi bila kadar oksidan lebih tinggi dari pada kadar antioksidan baik antioksidan enzimatis maupun non-enzimatis sehingga dapat merusak atau mengoksidasi biomolekul di dalam tubuh termasuk DNA2. Wanita usia subur (WUS) merupakan salah satu kelompok yang rentan terhadap masalah gizi $^{4}$. Wanita pekerja dengan posisi berdiri merupakan bagian dari WUS yang berisiko mengalami stres oksidatif ${ }^{7}$. Oleh karena itu penelitian ini bertujuan menguji pengaruh vitamin C dibandingkan dengan multi vitamin-mineral terhadap status zat gizi antioksidan pada wanita pekerja yang dalam penelitian ini sebagian besar bekerja dalam posisi berdiri.

\section{BAHAN DAN CARA}

Desain, Waktu dan Tempat

Desain penelitian adalah eksperimental murni terandomisasi buta ganda (Double Blind Randomized Controlled Trial) yang dilaksanakan mulai Februari 2008-
Desember 2008 dan dilakukan di Pabrik Garmen PT RPG di Citeurep Kabupaten Bogor.

\section{Sampel Penelitian}

Sampel penelitian adalah Wanita Pekerja (20 - 45 tahun), dengan kriteria inklusi sehat secara fisik dan klinis, tidak minum alkohol dan merokok serta bersedia mengikuti tahapan penelitian. Jumlah minimal sampel dihitung dengan rumus beda rata-rata dua kelompok dari Lemeshow ${ }^{8}$ dengan tingkat kesalahan $(\alpha)=5 \%$, power of test $=90 \%$, Standar deviasi dari penelitian penelitian Jong et al. ${ }^{9}=0.22, \delta=0.2$ adalah 25 sampel dan untuk antisipasi drop out di tambah 30 persen sehingga total sampel 33 sampel.

\section{Bahan Intervensi}

Bahan intervensi yakni suplemen multi vitamin-mineral, suplemen vitamin C 1000 $\mathrm{mg}$ dan plasebo diproduksi secara sentral oleh P.T. B I. Komposisi suplemen Multi Vitamin-Mineral (MVM) terdiri dari $1000 \mathrm{mg}$ vitamin $\mathrm{C} ; 45 \mathrm{mg}$ vitamin $\mathrm{E} ; 700 \mu \mathrm{g}$ vitamin $A ; 6,5 \mathrm{mg}$ vitamin $B_{6} ; 400 \mu \mathrm{g}$ asam folat; 9,6 $\mu \mathrm{g}$ vitamin $\mathrm{B}_{12} ; 10 \mu \mathrm{g}$ vitamin $\mathrm{D} ; 10 \mathrm{mg} \mathrm{Zn}$; $110 \mu \mathrm{g} \mathrm{Se} ; 0,9 \mathrm{mg} \mathrm{Cu}$; dan 5 mg Fe. Bentuk dan ukuran ketiga suplemen dibuat dalam kemasan tablet yang sama. Jenis suplemen yang diberikan kepada masing-masing sampel penelitian tidak diketahui baik oleh peneliti maupun oleh petugas lapang. Pengacakan sampel maupun perlakuan hanya diketahui oleh petugas khusus yang tidak terlibat dalam penelitian.

\section{Cara Pengumpulan Data}

Status vitamin C ditentukan dengan cara pemeriksaan kadar vitamin $\mathrm{C}$ dalam plasma menggunakan Spectrophotometer. Berdasarkan Gibson $^{10}$. kekurangan vitamin C bila kadar plasma vitamin $C<11.4 \mu \mathrm{mol} / \mathrm{L}$. Status vitamin $\mathrm{E}$ ditentukan dengan cara pemeriksaan kadar vitamin $E$ dalam serum menggunakan metode HPLC. Dinyatakan defisiensi vitamin $\mathrm{E}$ bila kadar serum vitamin $\mathrm{E}<11.6 \mu \mathrm{mol} / \mathrm{L}$ berdasarkan Gibson ${ }^{10}$. Status vitamin A juga ditentukan dengan cara pemeriksaan kadar vitamin A dalam serum menggunakan metode HPLC. 
Dinyatakan defisiensi vitamin A bila kadar serum vitamin $A<0.7 \mu \mathrm{mol} / \mathrm{L}$ berdasarkan Gibson ${ }^{10}$.

\section{Pengolahan dan Analisis Data}

Data dianalisis secara deskriptif dan inferensia. Uji ANOVA dan BNT (beda nyata terkecil) digunakan untuk mengetahui variabel yang mempengaruhi perlakuan.

\section{HASIL}

Dari 99 sampel pada awal penelitian, setelah akhir penelitian sebanyak 92 sampel yang mengikuti sampai penelitian berakhir terdiri dari 29 sampel pada perlakuan placebo, perlakuan vitamin C sebanyak 31 sampel dan multi vitamin-mineral (MVM)sebanyak 32 sampel. Pengurangan sampel terjadi karena dilarang suami, sakit, hamil, berhenti bekerja, dan tidak mau diambil darah.

Pada Tabel 1, terlihat bahwa sebaran sampel berdasarkan pengategorian pendidikan bervariasi mulai dari tidak tamat SD sampai dengan Tamat SLTA. Persentase sampel yang tidak tamat SD relatif sedikit, yaitu 8.7 persen. Persentase terbesar pendidikan sampel pada penelitian ini adalah tamat Sekolah Lanjutan Tingkat Pertama (SLTP) yaitu sebesar 35.9 persen, diikuti dengan tamat Sekolah Lanjutan Tingkat Atas (SLTA) sebesar 29.3 persen dan sekitar 26 persen tamat Sekolah Dasar (SD). Berdasarkan hasil penelitian ini, tingkat pendidikan sampel tergolong cukup baik dan sudah memenuhi wajib belajar 9 tahun yang diprogramkan oleh Pemerintah.

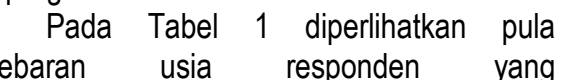
dikelompokkan berdasarkan Saidin dkk. yaitu antara usia 20-29 tahun, 30-39 tahun, dan $\geq$ 40 tahun $^{11}$. Berdasarkan kategori usia, sebagian besar sampel berusia antara 30-39 tahun sebanyak 42.4 persen dan berikutnya sebanyak 50 persen berusia antara 20-29 tahun, sisanya hanya 7.6 persen berusia 4045 tahun. Menurut Atmarita dan Fallah, usia sampel penelitian ini termasuk kedalam kategori kisaran usia produktif yakni antara usia 20-45 tahun ${ }^{12}$.

Tabel 1

Karakteristik Sampel

\begin{tabular}{lcc}
\hline Karakteristik sampel & $\mathrm{n}$ & $\%$ \\
\hline Pendidikan: & 8 & \\
Tidak tamat SD & 24 & 8.7 \\
Tamat SD & 33 & 26.1 \\
Tamat SLTP & 27 & 35.9 \\
Tamat SLTA & & 29.3 \\
\hline Usia & 46 & \\
20 - 29 Tahun & 39 & 50.00 \\
30 - 39 Tahun & 7 & 42.39 \\
$>$ 40 Tahun & & 7.61 \\
\hline Ukuran Keluarga & 85 & \\
$<4$ Orang & 7 & 92.39 \\
5-7 Orang & & 7.61 \\
\hline Status Gizi & 1 & \\
Sangat Kurus & 5 & 1.09 \\
Kurus & 58 & 5.43 \\
Normal & 17 & 63.04 \\
Overweight & 11 & 18.48 \\
Obesitas & & 11.96 \\
\hline
\end{tabular}


Sebaran jumlah anggota keluarga sampel juga dapat dilihat pada Tabel 1. Besarnya jumlah anggota keluarga mempengaruhi jumlah dan jenis makanan yang dikonsumsi anggota keluarga dan selanjutnya akan berpengaruh terhadap status gizi seseorang. Menurut $\mathrm{BKKBN}^{13}$, jumlah anggota keluarga dapat dikelompokkan menjadi keluarga kecil dengan jumlah anggota keluarga kurang dari atau sama dengan 4 orang, keluarga sedang dengan jumlah anggota keluarga 5-7 orang, dan keluarga besar dengan jumlah anggota keluarga lebih dari 7 orang. Sebagian besar sampel penelitian ini termasuk dalam kategori keluarga kecil dengan jumlah anggota keluarga kurang dari atau sama dengan 4 orang (92.4 persen) yang berarti keluarga tersebut mempunyai anak antara 1 2 orang, sisanya 7.6 persen termasuk dalam kategori keluarga sedang.

Status gizi sampel penelitian ini diukur menggunakan indikator Indeks Massa Tubuh (IMT). Sebagian besar sampel tergolong dalam status gizi baik yakni sebanyak 63.0 persen, tetapi terdapat 6.4 persen sampel termasuk dalam kategori kurus dan sangat kurus, sebaliknya sekitar 30 persen sampel termasuk dalam kategori gizi lebih (overweight) dan obesitas ${ }^{14}$.

Ditemukannya sampel dengan gizi kurang dan lebih dalam penelitian ini menunjukan bahwa pada populasi ini terdapat masalah gizi ganda. Adanya kejadian gizi lebih pada sampel penelitian yang relatif besar persentasenya menunjukkan bahwa masalah gizi lebih tidak hanya terjadi pada kelompok masyarakat dengan tingkat sosial ekonomi tinggi tetapi juga sudah banyak dijumpai pada kelompok masyarakat tingkat sosial ekonomi menengah kebawah seperti pada kelompok sampel penelitian ini. Salah satu penyebab timbulnya masalah gizi lebih pada usia dewasa adalah status gizi yang kurang atau buruk pada usia dini ${ }^{15}$.

Tabel 2 menunjukkan bahwa keseluruhan karakteristik sampel yang meliputi usia, pendidikan, jumlah anggota keluarga, status gizi sebelum penelitian tidak ada perbedaan antara ketiga perlakuan $(p>0.05)$.

Tabel 2

Sebaran Karakteristik Sampel Menurut Perlakuan

\begin{tabular}{lcccc}
\hline Karakteristik & Plasebo & Vit. C & MVM & $p$ \\
\hline Usia & $31.0+4.5$ & $31.6+5.9$ & $31.3+4.8$ & 0.323 \\
Pendidikan & $9.34+2.47$ & $8.21+2.77$ & $8.52+2.70$ & 0.098 \\
Jumlah Anggota Keluarga & $3.3+0.7$ & $3.5+0.7$ & $3.7+0.7$ & 0.210 \\
Indeks Massa Tubuh & $23.7+3.4$ & $22.2+3.2$ & $23.5+3.1$ & 0.130 \\
\hline
\end{tabular}

\section{Pengaruh suplementasi terhadap kadar zat gizi antioksidan Vitamin A}

$\beta$ karoten sebagai prekursor vitamin $A$ merupakan antioksidan larut lemak yang berperan di dalam mempertahankan kesehatan mata dan integritas membran sel menjadikan senyawa ini bersifat vital bagi manusia. $\beta$-karoten sebagai pro-vitamin A sangat berperan di dalam "quenching" yaitu proses menginaktifkan molekul yang elektronnya tereksitasi. $\quad \beta$-karoten melepaskan electron pada ikatan rangkap duanya kepada radikal bebas, misalnya ${ }^{1} \mathrm{O}_{2}$ $+\beta$-karoten menghasilkan ${ }^{3} \mathrm{O}_{2}+\beta$-karoten yang tereksitasi. Kekuatan $\beta$-karoten di dalam menginaktifkan radikal bebas dibandingkan dengan antioksidan lainnya dapat diurutkan sebagai berikut : lycopen > vitamin $E>\alpha$ - karoten $>\beta$-cryptosantin $>\beta$ karoten $>$ lutein. Kekuatan sebagai antioksidan akan lebih besar bila lycopen dan lutein bergabung dibandingkan bekerja sendiri- sendiri' ${ }^{16}$. 
Vitamin A yang terdapat di dalam makanan sebagian besar terdapat dalam bentuk ester retinil, bersama karotenoid bercampur dengan lipida lain di dalam lambung. Di dalam sel-sel mukosa usus halus, ester retinil dihidrolisis oleh enzimenzim pankreas esterase menjadi retinol yang lebih efisien diabsorpsi daripada ester retinil. Sebagian dari karotenoid, terutama $\beta$ karoten di dalam sitoplasma sel mukosa usus halus dipecah menjadi retinol ${ }^{17}$.

Hasil penelitian ini menunjukan bahwa sebelum suplementasi, rata-rata kadar vitamin A pada perlakuan plasebo $1.00 \pm$
$0.31 \mu \mathrm{mol} / \mathrm{l}$, Vitamin C 0.96 $0.27 \mu \mathrm{mol} / \mathrm{l}$, dan MVM $1.11 \pm 0.38 \mu \mathrm{mol} / \mathrm{l}$. Hasil uji statistik menunjukkan rata-rata kadar vitamin A pada ketiga perlakuan tidak berbeda makna ( $p>0.05)$. (Tabel 3).

Setelah 10 minggu suplementasi terjadi perubahan kadar vitamin $A$, yakni kadar vitamin $A$ pada perlakuan plasebo menjadi $0.95 \pm 0.32 \mu \mathrm{mol} / \mathrm{l}$, Vitamin C $0.98 \pm 0.26$ $\mu \mathrm{mol} / \mathrm{l}$, dan MVM $1.13 \pm 0.42 \mu \mathrm{mol} / \mathrm{l}$. Hasil uji statistik menunjukkan rata-rata perubahan kadar vitamin A tidak berbeda nyata antara ketiga perlakuan $(p>0.05)$.

Tabel 3

Rata-rata Kadar Vitamin A Selama Suplementasi Menurut Perlakuan

\begin{tabular}{|c|c|c|c|c|}
\hline \multirow{2}{*}{ Suplementasi } & \multicolumn{3}{|c|}{ Kadar Serum Vitamin A (umol/l) } & \multirow{2}{*}{ p } \\
\hline & Placebo $^{a}$ & Vit. $C^{a}$ & MVM $^{a}$ & \\
\hline Sebelum & $1.00 \pm 0.31^{\mathrm{c}}$ & $0.96 \pm 0.27^{c}$ & $1.11 \pm 0.38^{c}$ & 0.170 \\
\hline Sesudah & $0.95 \pm 0.32^{c}$ & $0.98 \pm 0.26^{c}$ & $1.13 \pm 0.42^{c}$ & 0.108 \\
\hline Selisih ${ }^{b}$ & $-0.05 \pm 0.27^{c}$ & $0.02 \pm 0.23^{c}$ & $0.02 \pm 0.36^{c}$ & 0.576 \\
\hline
\end{tabular}

Keterangan:

${ }^{a}$ Grup Perlakuan

b Selisih sesudah dengan sebelum suplementasi

${ }^{\mathrm{C}}$ Rataan \pm Standard Deviation; $(-)=$ menurun dari data sebelumnya.

Tidak adanya perubahan kadar vitamin A pada ketiga perlakuan, kemungkinan karena status vitamin A sampel sebelum suplementasi dalam keadaan normal $>0.7$ $\mu \mathrm{mol} / \mathrm{l})$, sehingga pemberian Multi vitaminmineral (MVM) atau vitamin C tidak banyak berpengaruh. Temuan ini sejalan dengan hasil penelitian Kay et al. dan Wolters et al. dimana suplementasi multi vitamin-mineral tidak memperbaiki status vitamin A sampel karena status vitamin A pada saat baseline dalam keadaan normal ${ }^{18,19}$.

\begin{abstract}
Vitamin E
Vitamin E atau a-tokoferol merupakan antioksidan yang larut dalam lemak. Vitamin ini banyak terdapat dalam membran eritrosit dan lipoprotein plasma. Vitamin E terutama cincin fenolnya mampu memberikan ion hidrogennya kepada radikal bebas. Diantara beberapa bentuk vitamin $E$, bentuk atocoferol lebih efektif dibandingkan dengan beta, gama dan delta tocoferol. lon hidrogen dari a-tocoferol sangat efektif dan cepat bereaksi dengan beberapa radikal bebas dan menghentikannya sebelum menghancurkan membran sel dan komponen-komponen sel lainnya.
\end{abstract}


Tabel 4

Rata-rata Kadar Vitamin E Selama Suplementasi Menurut Perlakuan

\begin{tabular}{ccccc}
\hline & \multicolumn{3}{c}{ Vitamin $\mathrm{E}($ umol/l) } & \multirow{2}{*}{$\mathrm{p}$} \\
\cline { 2 - 4 } Suplementasi & Placebo $^{\mathrm{a}}$ & Vit. $\mathrm{C}^{\mathrm{a}}$ & $\mathrm{MVM}^{\mathrm{a}}$ & \\
\hline Sebelum & $8.9 \pm 2.2^{\mathrm{c}}$ & $8.6 \pm 2.6^{\mathrm{c}}$ & $8.9 \pm 2.9^{\mathrm{c}}$ & 0.867 \\
Sesudah & $9.5 \pm 2.3^{\mathrm{c}}$ & $9.2 \pm 2.5^{\mathrm{c}}$ & $13.5 \pm 4.2^{\mathrm{c}}$ & 0.000 \\
Selisih $^{\mathrm{b}}$ & $0.6 \pm 1.4^{\mathrm{c}}$ & $0.6 \pm 1.3^{\mathrm{c}}$ & $4.6 \pm 3.1^{\mathrm{c}}$ & 0.000 \\
\hline
\end{tabular}

Keterangan:

a Grup Perlakuan

${ }^{\mathrm{b}}$ Selisih sesudah dengan sebelum suplementasi

${ }^{\mathrm{c}}$ Rataan + Standard Deviation

Hasil penelitian menunjukkan bahwa sebelum suplementasi, rata-rata kadar vitamin $\mathrm{E}$ pada perlakuan plasebo yakni 8.9 $\pm 2.2 \mu \mathrm{mol} / \mathrm{L}$, vitamin C $8.6 \pm 2.6 \mu \mathrm{mol} / \mathrm{L}$, MVM $8.9 \pm 2.9 \mu \mathrm{mol} / \mathrm{L}$. Hasil uji statistik menunjukkan bahwa rata-rata kadar vitamin E pada ketiga perlakuan tidak berbeda nyata ( $p>0.05)$. (Tabel 4).

Setelah 10 minggu suplementasi terjadi peningkatan kadar vitamin E, yakni kadar vitamin $\mathrm{E}$ pada perlakuan plasebo menjadi $9.5 \pm 2.3 \mu \mathrm{mol} / \mathrm{L}$, vitamin $\mathrm{C} 9.2 \pm 2.5 \mu \mathrm{mol} / \mathrm{L}$, dan MVM 13.54 $\pm 4.2 \mu \mathrm{mol} / \mathrm{L}$ (Tabel 4). Hasil uji statistik menunjukkan bahwa rata-rata kadar vitamin $\mathrm{E}$ pada ketiga perlakuan berbeda nyata $(p<0.05)$. Uji Anova dan BNT menunjukkan suplementasi MVM mempengaruhi kenaikan kadar vitamin $\mathrm{E}$ secara signifikan. Temuan ini menunjukkan bahwa suplementasi MVM lebih berpengaruh dalam peningkatan vitamin $\mathrm{E}$ dibandingkan suplementasi vitamin $\mathrm{C}$ maupun plasebo. Hal ini kemungkinan karena suplemen multivitamin mineral (MVM) mengandung vitamin E sebesar $45 \mathrm{mg}$ (300 RDA), oleh karena itu pemberian vitamin $E$ selama 10 minggu mampu meningkatkan kadar vitamin $\mathrm{E}$ serum sampel karena status vitamin E sampel pada awal penelitian rendah.

\section{Vitamin C}

Vitamin C merupakan antioksidan yang larut dalam air (aqueous antioxidant). Peranan vitamin C sebagai antioksidan, ditunjukkan oleh kemampuan vitamin C dalam menyumbangkan elektron ke dalam reaksi biokimia intraseluler dan ekstraseluler sehingga vitamin $\mathrm{C}$ mampu menghilangkan senyawa oksigen reaktif di dalam sel seperti sel netrofil, monosit, sel retina ${ }^{2}$.

Vitamin C juga diperlukan dalam proses regenerasi vitamin $\mathrm{E}$ teroksidasi. Oleh karena itu keberadaan vitamin $C$ sangat membantu regenerasi vitamin $E$ sehingga dapat berperan kembali di dalam memutus rantai radikal bebas. Selain itu, vitamin $\mathrm{C}$ juga dapat menginduksi pelepasan besi ferri dari ferritin dengan mereduksi besi menjadi ferro ${ }^{16}$.

Hasil penelitian ini menunjukkan bahwa sebelum suplementasi, rata-rata kadar vitamin $C$ pada perlakuan plasebo yakni $10.28 \pm 2.8 \mu \mathrm{mol} / \mathrm{L}$, Vitamin C $10.48 \pm 2.4$ $\mu \mathrm{mol} / \mathrm{L}$, dan MVM $11.22 \pm 3.0 \mu \mathrm{mol} / \mathrm{L}$. Hasil uji statistik menunjukkan bahwa rata-rata kadar vitamin $C$ tidak berbeda nyata antara ketiga perlakuan ( $p>0.05)$. (Tabel 5).

Setelah suplementasi selama sepuluh minggu, terjadi perubahan kadar vitamin $\mathrm{C}$ sampel yaitu pada plasebo $9.79 \pm 2.2 \mu \mathrm{mol} / \mathrm{l}$, Vitamin C $15.13 \pm 3.12$, MVM $10.85 \pm 3.01$ $\mu \mathrm{mol} / /$. . Hasil uji statistik menunjukkan bahwa rata-rata kadar vitamin $C$ ketiga perlakuan berbeda nyata $(p<0.05)$. Hasil uji Anova dan BNT menunjukkan suplementasi vitamin $\mathrm{C}$ mempengaruhi kenaikan kadar vitamin $\mathrm{C}$ secara signifikan pada sampel yang mendapat suplemen vitamin $\mathrm{C}$. 
Tabel 5

Rata-rata Kadar Vitamin C Menurut Perlakuan Selama Suplementasi

\begin{tabular}{lcccc}
\hline \multirow{2}{*}{ Suplementasi } & \multicolumn{3}{c}{ Kadar Serum Vitamin C (umol/l) } & \multirow{2}{*}{$p$} \\
\cline { 2 - 4 } & Placebo $^{\mathrm{a}}$ & Vit. C & MVM $^{\mathrm{a}}$ & \\
\hline Sebelum & $10.28 \pm 2.8^{\mathrm{c}}$ & $10.48 \pm 2.4^{\mathrm{c}}$ & $11.22 \pm 3.0^{\mathrm{c}}$ & 0.482 \\
Sesudah & $9.79 \pm 2.2^{\mathrm{c}}$ & $15.13 \pm 3.12^{\mathrm{c}}$ & $10.85 \pm 3.01^{\mathrm{c}}$ & 0.000 \\
Selisih $^{\mathrm{b}}$ & $-0.49 \pm 3.09^{\mathrm{c}}$ & $4.65 \pm 2.54^{\mathrm{c}}$ & $-0.37 \pm 4.6^{\mathrm{c}}$ & 0.000 \\
\hline
\end{tabular}

Keterangan:

a Grup Perlakuan

${ }^{\mathrm{b}}$ Selisih sesudah dengan sebelum suplementasi

${ }^{\mathrm{c}}$ Rataan \pm Standard Deviation; $(-)=$ menurun dari data sebelumnya.

\section{SOD(Superoksida Dismutase)}

Secara normal tubuh kita berada dalam keseimbangan antara produksi radikal bebas dengan antioksidan, baik antioksidan nonenzimatis maupun enzimatis. Akan tetapi perubahan gaya hidup stress dan aktifitas fisik yang tinggi dapat mengakibatkan terjadinya ketidak seimbangan tersebut ${ }^{20}$.
Superoksida dismutase (SOD) merupakan antioksidan enzimatis selain katalase dan glutathione peroksidase (GSH-PX). Enzimenzim ini bekerja dengan cara melindungi sel dan jaringan dari kerusakan oksidatif yang disebabkan oleh radikal bebas oksigen seperti anion superoksida $\left(\mathrm{O}_{2}^{-}\right)$, radikal hidroksil $(\cdot \mathrm{OH})$ dan hidrogen peroksida $\left(\mathrm{H}_{2} \mathrm{O}_{2}\right)$.

Tabel 6

Rata-rata Kadar SOD Selama Penelitian Menurut Perlakuan

\begin{tabular}{lcccc}
\hline \multirow{2}{*}{ Suplementasi } & \multicolumn{3}{c}{ Kadar SOD } & \multirow{2}{*}{$p$} \\
\cline { 2 - 4 } & Placebo $^{\mathrm{a}}$ & Vit. C $^{\mathrm{a}}$ & MVM $^{\mathrm{a}}$ & \\
\hline Sebelum & $1218 \pm 514^{\mathrm{c}}$ & $1199 \pm 533^{\mathrm{c}}$ & $1020 \pm 357^{\mathrm{c}}$ & 0.204 \\
Sesudah & $1280 \pm 409^{\mathrm{c}}$ & $1222 \pm 405^{\mathrm{c}}$ & $1552 \pm 584^{\mathrm{c}}$ & 0.021 \\
Selisih $^{\mathrm{b}}$ & $62 \pm 571^{\mathrm{c}}$ & $23 \pm 607^{\mathrm{c}}$ & $532 \pm 550^{\mathrm{c}}$ & 0.001 \\
\hline
\end{tabular}

Keterangan:

${ }^{a}$ Grup Perlakuan

${ }^{\mathrm{b}}$ Selisih sesudah dengan sebelum suplementasi

${ }^{\mathrm{c}}$ Rataan \pm Standard Deviation.

Enzim SOD berfungsi sebagai katalisator reaksi dismutasi dari anion superoksida menjadi hidrogen peroksida $\left(\mathrm{H}_{2} \mathrm{O}_{2}\right)$. Sebenarnya enzim ini sudah ada dalam tubuh namun memerlukan bantuan zat zat gizi seperti $\mathrm{Cu}, \mathrm{Mn}$ dan $\mathrm{Zn}$ agar bisa bekerja optimal.

Hasil penelitian ini menunjukkan bahwa sebelum suplementasi, rata-rata kadar SOD

pada perlakuan plasebo yakni $1218 \pm 514$ unit/gr $\mathrm{Hb}$, Vitamin C $1199 \pm 533$ unit/gr $\mathrm{Hb}$, dan MVM $1020 \pm 357$ unit/gr Hb. Hasil uji statistik menunjukkan bahwa rata-rata kadar SOD tidak berbeda nyata antara ketiga perlakuan ( $p>0.05$ ) (Tabel 6$)$.

Setelah suplementasi selama sepuluh minggu, terjadi perubahan kadar SOD sampel yaitu pada plasebo $1280 \pm 409$ 
unit/gr $\mathrm{Hb}$, vitamin $\mathrm{C} 1222+405$ unit/gr $\mathrm{Hb}$, MVM $1552 \pm 584$ unit/grHb. Hasil uji statistik menunjukkan bahwa rata-rata kadar SOD ketiga perlakuan berbeda nyata $(p<0.05)$. Uji Anova dan BNT menunjukkan suplementasi MVM mempengaruhi kenaikan kadar SOD secara signifikan.

\section{Perubahan status zat gizi antioksidan selama suplementasi}

Hasil penelitian menunjukkan bahwa sesudah suplementasi terjadi perubahan status zat gizi antioksidan sampel. Pada sampel yang mendapat perlakuan suplementasi plasebo hampir tidak mengalami perubahan persentase kekurangan zat gizi antioksidan. Pada sampel yang mendapat suplementasi vitamin C mengalami penurunan persentase kekurangan vitamin $C$ dari 60.9 persen menjadi 8.7 persen, sedangkan sampel yang mendapat suplementasi MVM mengalami penurunan persentase kekurangan vitamin $A$ dari 13.3 persen menjadi 6.7 persen, vitamin E dari 75 persen menjadi 40.6 persen, penurunan vitamin $C$ dari 62 persen menjadi 58 persen dan penurunan persentase sampel yang mempunyai kadar SOD dibawah normal dari 64.5 persen menjadi 16 persen (Tabel 7).

Tabel 7

Persentase Kekurangan Zat Gizi Antioksidan Sebelum dan Sesudah Penelitian

\begin{tabular}{lcccccccccccc}
\hline & \multicolumn{4}{c}{ Plasebo } & \multicolumn{4}{c}{ Vitamin C } & \multicolumn{3}{c}{ Multi vitamin-mineral } \\
\cline { 2 - 15 } Zat Gizi & \multicolumn{2}{c}{ Sebelum } & \multicolumn{2}{c}{ Sesudah } & \multicolumn{2}{c}{ Sebelum } & \multicolumn{2}{c}{ Sesudah } & \multicolumn{2}{c}{ Sebelum } & \multicolumn{2}{c}{ Sesudah } \\
& $\mathrm{n}$ & $\%$ & $\mathrm{n}$ & $\%$ & $\mathrm{n}$ & $\%$ & $\mathrm{n}$ & $\%$ & $\mathrm{n}$ & $\%$ & $\mathrm{n}$ & $\%$ \\
\hline Vitamin A & 5 & 19.9 & 7 & 25 & 5 & 17.5 & 4 & 14.3 & 4 & 13.3 & 2 & 6.7 \\
Vitamin E & 23 & 79.3 & 23 & 79.3 & 25 & 80.6 & 21 & 67.7 & 24 & 75 & 13 & 40.6 \\
Vitamin C & 17 & 81 & 16 & 76.2 & 14 & 60.9 & 2 & 8.7 & 15 & 62.5 & 14 & 58.3 \\
SOD & 12 & 40 & 13 & 43 & 13 & 48.1 & 11 & 40.7 & 20 & 64.5 & 5 & 16.1 \\
\hline
\end{tabular}

\section{BAHASAN}

Vitamin C dikenal luas sebagai antioksidan. Kekuatan vitamin C sebagai antioksidan larut air disebabkan karena kemampuan vitamin $\mathrm{C}$ dalam mereduksi. Vitamin $\mathrm{C}$ antara lain mereduksi superoxide menjadi hidrogen peroksida, atau $\mathrm{Fe} 3+$ menjadi $\mathrm{Fe} 2+$, atau reduksi unsur logam lainnya. Setelah perpindahan satu elektron, vitamin C menghasilkan radikal monodehydroascorbate. Radikal ini akan berubah menjadi askorbat dan dehydroaskorbat. Kebanyakan jaringan tubuh mempunyai enzim glutathionedependent monodehydroascorbat reductase dan NADPH yang akan mereduksi radikal tersebut menjadi askorbat kembali. Dehydroaskorbat tidak stabil dalam larutan, dan akan mengalami pemecahan gugus cincinnya menjadi diketogulonic acid. Akan tetapi, dehydroaskorbat biasanya direduksi oleh NADPH atau glutathione dependent reductase menjadi askorbat ${ }^{23}$. Vitamin $\mathrm{C}$ juga diperlukan dalam beberapa proses di dalam tubuh seperti biosintesis, carnitin yang mentransfer lemak, hormon adrenalin, cortison, transpor elektron dalam banyak reaksi enzimatik, melindungi integritas dari pembuluh darah, melindungi gusi dan meningkatkan fungsi imunitas ${ }^{24}$.

Kekurangan vitamin C dapat menimbulkan tanda-tanda klinis seperti pendarahan atau bengkak di gusi, nyeri persendian, atau konsentrasi vitamin $\mathrm{C}$ di plasma, darah dan leukosit yang sangat rendah. Kekurangan vitamin C akut dapat menyebabkan skorbut. Seseorang dengan kekurangan vitamin $\mathrm{C}$ dapat menurunkan kekebalan seluler ${ }^{25}$.

Kelebihan vitamin C dari makanan jarang terjadi, akan terjadi jika 
mengkonsumsi suplemen vitamin $C$ secara berlebihan, dimana dapat menimbulkan hiperoksaluria dan resiko lebih tinggi yaitu terbentuk batu ginjal ${ }^{17}$. Efek samping lainnya bila mengonsumsi vitamin $\mathrm{C}$ dosis tinggi yaitu dapat mengganggu saluran pencernaan dan diare ${ }^{2}$, akan tetapi selama mengonsumsi dengan dosis di bawah Upper Limit (UL) yaitu $2000 \mathrm{mg} / \mathrm{hari}$ tidak menimbulkan efek negatif ${ }^{26}$.

Vitamin $\mathrm{E}$ merupakan antioksidan larut lemak terbesar di dalam sistem pertahanan antioksidan sel dan hanya didapat dari makanan. Peranan besar vitamin E adalah melindungi poly unsaturated fatty acid (PUFAs) dan komponen lain dari membran sel dan low-density lipoprotein (LDL) dari oksidasi oleh radikal bebas. Vitamin $\mathrm{E}$ terletak di dalam lapisan phospolipid dari membran sel, sehingga sangat efektif dalam melindungi kerusakan lemak tak jenuh ${ }^{2,17}$.

Vitamin $E$ juga mempunyai fungsi utama sebagai chain-breaking antioxidant. Vitamin $\mathrm{E}$ memberikan hidrogen dari grup hydroksil $(-\mathrm{OH})$ pada struktur radikal bebas, sehingga radikal bebas menjadi tidak reaktif. Vitamin $\mathrm{E}$ menghentikan peroksidasi lemak radikal bebas dengan memberikan elektron tunggal untuk membentuk tokoferil kuinon yang stabil dan teroksidasi sempurna ${ }^{21}$,oleh karena itu keberadaan vitamin $\mathrm{E}$ di dalam tubuh sangat diperlukan.

Salah satu radikal bebas yang banyak ditemukan di dalam tubuh kita adalah superoksida. Radikal superoksida terbentuk ketika oksigen tereduksi, yang terjadi di membrane mitokondria bagian dalam. Radikal ini dapat memicu reaksi berantai pada asam lemak phospholipid, sehingga terjadi peroksidasi lipid pada membran dan hilangnya lapisan membran yang penting untuk fungsi reseptor dan enzim yang terikat pada membran. Dalam keadaan stres oksidatif, lebih banyak radikal oksigen dihasilkan, melebihi antioksidan seluler, dan akan menyebabkan peroksidasi asam lemak tak jenuh-ganda pada struktur membran. Peroksidasi lipid juga akan melepas radikal bebas reaktif dan juga aldehid yang toksik, yang akan menginaktivasi enzim dan komponen seluler lainnya secara menyeluruh. Beberapa antioksidan enzimatik dan non-enzimatik ada di dalam sel untuk melindungi membran sel dan organ sel lainnya dari efek reaksi radikal bebas yang merusak $^{22}$.

Salah satu kelompok rawan terpapar stres oksidatif adalah para pekerja dengan berdiri. Kelompok ini beresiko terkena hipertensi vena tungkai bawah yang merupakan pemicu terjadinya CVI (chronic venous insufficiency). Kerusakan dinding pembuluh darah ini diantaranya dimediasi oleh SOR (spesies oksigen reaktif) diantaranya radikal superoksida yang berperan melalui dua mekanisme. Yang pertama adalah melalui oksidasi membran dan dilanjutkan dengan kerusakan endothelium yang akan berujung pada meningkatnya permeabilitas vaskuler. Mekanisme yang kedua adalah melalui kemotaksis dan aktivasi leukosit dan trombosit. Kedua mekanisme ini terjadi bersamaan dan akan meningkatkan kerusakan sel dan memperburuk cloting pada vena ${ }^{7}$. Spesies oksigen reaktif dapat terbentuk ketika metabolisme normal atau dari luar tubuh seperti polutan dan radiasi ultra violet ${ }^{2,16}$. Untuk dapat menangkal SOR diperlukan konsumsi zat gizi antioksidan seperti vitamin $\mathrm{E}$ dan vitamin $\mathrm{C}$ yang cukup.

Hasil penelitian ini menunjukkan bahwa pemberian multi vitamin-mineral pada wanita pekerja dapat meningkatkan kadar vitamin $\mathrm{E}$, dan kadar SOD secara signifikan $(p<0.05)$, sementara itu pemberian single vitamin $C$ hanya memperbaiki status vitamin $C$ darah sampel yang mendapat perlakuan suplementasi vitamin C secara signifikan $(p<0.05)$, namun tidak cukup kuat di dalam menangkal radikal bebas. Hal ini lebih disebabkan karena single vitamin C tidak berinteraksi dengan vitamin atau mineral lainnya sehingga vitamin $C$ yang diterima oleh tubuh dapat segera diserap oleh tubuh untuk memperbaiki status vitamin $\mathrm{C}$, karena status vitamin $\mathrm{C}$ sampel pada awal penelitian dalam keadaan rendah. Sementara itu vitamin $\mathrm{C}$ yang terdapat di dalam suplemen MVM berinteraksi dengan vitamin lainnya seperti membantu kerja dari vitamin $E$ sebagai pemutus rantai radikal bebas. 
Seperti di ketahui bahwa vitamin E dikenal sebagai antioksidan yang mampu menghentikan rantai reaksi radikal bebas (chain breaking antioxidant). Dengan menyumbangkan hidrogen, vitamin $\mathrm{E}$ sendiri menjadi vitamin $E$ teroksidasi ${ }^{16,21}$. Vitamin $E$ teroksidasi yang terbentuk dapat diregenerasi oleh senyawa pereduksi seperti vitamin C sehingga vitamin E kembali menjadi vitamin $\mathrm{E}$ bebas dan kemudian dapat bekerja kembali memutus rantai radikal bebas. Keadaan ini terlihat pada hasil penelitian ini dimana vitamin $\mathrm{C}$ yang terdapat di dalam MVM kurang digunakan untuk memperbaiki status vitamin $\mathrm{C}$ tetapi membantu menangkal radikal bebas dengan membaiknya status SOD sebagai salah satu marker antioksidan. Membaiknya status SOD menunjukkan bahwa tubuh sudah tidak banyak menggunakan SOD untuk menangkal radikal bebas, kemungkinan lainnya membaiknya status SOD karena pengaruh mineral yang terdapat di dalam komposisi MVM seperti Zn, Cu yang sangat mempengaruhi aktivitas SOD. Superoksida dismutase (SOD) adalah antioksidan enzimatis yang bekerja merubah radikal bebas menjadi radikal bebas yang kurang reaktif. Mekanisme kerja SOD dengan jelas dapat dilihat pada Gambar 1.

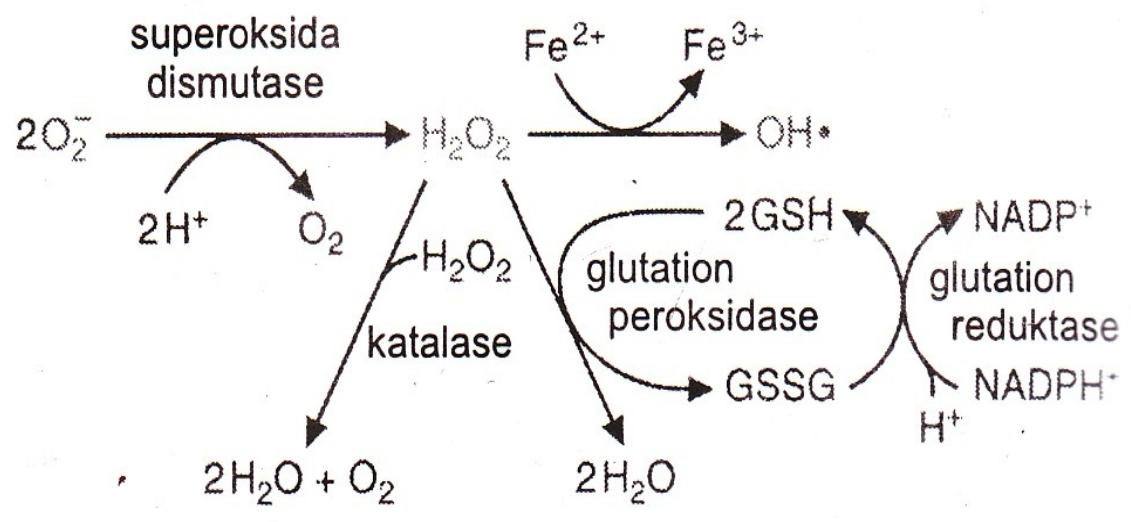

Gambar 1

Peranan SOD Dalam Menangkal Radikal Bebas

\section{KESIMPULAN}

1. Suplementasi multi vitamin-mineral mempengaruhi secara nyata $(p<0.05)$ kenaikan kadar vitamin $\mathrm{E}$ dan superoksida dismutase (SOD), namun suplementasi vitamin C $1000 \mathrm{mg}$ hanya mempengaruhi secara nyata $(p<0.05)$ kenaikan kadar vitamin C .

2. Suplementasi multi vitamin-mineral (MVM) mampu menurunkan radikal bebas dengan membaiknya kadar superoxide dismutase (SOD) secara nyata $(p<0.05)$ dibandingkan dengan single vitamin $\mathrm{C}$.

\section{SARAN}

Berdasarkan temuan penelitian ini supplementasi multi zat gizi mikro perlu dipertimbangkan untuk memperbaiki status zat gizi antioksidan wanita pekerja yang berisiko terpapar stres oksidatif.

\section{UCAPAN TERIMAKASIH}


1. Pimpinan PT Bayer Indonesia yang telah menyiapkan bahan intervensi dan bantuan dana penelitian.

2. LPPM-IPB yang telah memfasilitasi kerjasama PT Bayer dengan IPB sehingga penelitian dapat dilaksanaan dengan lancar.

3. Pimpinan PT Ricky Putra Globalindo,Tbk yang telah memberikan ijin melakukan penelitian di perusahaan tersebut.

4. Kepala Dinas Kesehatan Kabupaten Bogor yang telah memberikan ijin melakukan penelitian di wilayah Kabupaten Bogor.

\section{RUJUKAN}

1. Word Bank.Repositioning Nutrition as Central to Development, A Strategy Large-Scale Action. Washington,DC.

USA, 2006

2. [IOM] Institute of Medicine. Dietary Reference Intakes for Vitamin C, Vitamin E, Selenium, and Carotenoids. Washington DC: National Academy Press, 2000.

3. Winarsi H. Antioxidan Alami dan Radikal Bebas. Jakarta. Kanisius, 2007.

4. FAO/WHO. International Conference on Nutrition. World Declaration and Plan of Action for Nutrition.Roma: FAO,1992.

5. Andrianne B. Physiological role of antioxidant in the immune system. Symposium Antioxidant, Immune Response and Animal Function. Journal Dairy Sci, 1993; 76:2789-2794.

6. Bland J. Vitamin C: The Future Is Now. Keats Publishing,Inc, 1995.
7.

Flore $\mathrm{R}$, Gerardino L, et al. Enhanced oxidative stress in workers with a standing occupation. Occup Environ Med, 2004; 61: 548-550.

8. Lemeshow,S. Adequacy of sample size in health studies. Yogyakarta: Gajah Mada Press,1993.

9. Jong Nd, Gibson RS, et al. Selenium and Zinc Status are suboptimal in a sample of older New Zealand Women in a Community-Based Study. American society for Nutritional Sciences, 2001

10. Gibson Rosalind S. Principles of Nutritional Assessment. London. Oxford Press, 2005.

11. Saidin M, Sukati, Pengaruh Pemberian Tablet Besi dan Vitamin E pada Kadar Hemoglobin dan Status Besi Wanita Usia Subur yang diduga Menderita Thalasemia Karier. Penelitian Gizi dan Makanan, 2005; 26:1-9.

12. Atmarita dan Fallah TS. Analisis Situasi Gizi dan Kesehatan Masyarakat dalam Soekirman et al, editor. Widya Karya Pangan dan Gizi VII Ketahanan Pangan dan Gizi di Era Otonomi Daerah dan Globalisasi; Jakarta, 17-19 Mei 2004: LIPI, hIm 129143.

13. Badan Koordinasi Keluarga Berencana Nasional. Gerakan Keluarga Berencana dan Keluarga Sejahtera. Jakarta: BKKBN, 1998.

14. DepKes RI. Pedoman Praktis Menilai Status Gizi Orang Dewasa. Jakarta: Depkes, 1996.

15. Barker D.J.P. Mothers, Babies and Health in Later Life. Second Edition.Brisbane, 1998.

16. Gropper S.C, Smith JL, Groff JL. Advanced Nutrition and Human Metabolism. International Student Edition. Thomson Wadsworth. USA, 2005. 
17. Almatsier S. Prinsip Dasar IImu Gizi. Jakarta: PT Gramedia Pustaka Utama, 2006.

18. Mc Kay DL, Perrone G, Rasmussen $\mathrm{H}$, Dallal G, Hartman W, Cao G, Prior RL, Roubenoff $R$, Blumberg JB. The effects of a multivitamin/mineral supplement on micronutrient status, antioxidant capacity and cytokine production in healthy older adults consuming a fortified diet. Journal of the American College of Nutrition, 2000; 19:613-621.

19. Wolters M, Hermann S, Hahn. Effects of 6-month multivitamin supplementation on serum concentrations of alphatocopherol, beta-carotene, and vitamin $C$ in healthy elderly women. Int Vit Nutr Res.2004; 74(2):161-8.

20. Brambilla D, Mancuso C, Scuderi MR, Bosco $P$, Lempereur GC, Benedetto GD, Pezzino S, Bernardini R. The role of antioxidant supplement in immune system, neoplastic, and neurodegenerative disorders: a point an assessment of the risk/benefit profile. Nutrition Journal, 2008;7:29-46.
21. Marks D, Marks A, Smith C Biokimia Kedokteran Dasar. ECG, 2000.

22. Evans J William. Vitamin E, Vitamin $\mathrm{C}$ and Exercice. American Journal Clinical Nutrition, 2000.

23. Bender David A. Nutritional Biochemistry of the vitamins. Second edition. Cambridge University Press, 2003.

24. Goodman Sandra. Vitamin C the master Nutrient. Keats Publishing.USA,1991.

25. Chandra RK. Influence of micronutrient supplement on immune responses dan infection-related illness in 50-65 year old individuals. Nutrition Research, 2002; 22:5-11.

26. Hathcock JN, Azzi A, Blumberg J, Bray T, Dickinson A, Frei B, Jialal I, Johnston CS, Kelly FJ, Kraemer $\mathrm{K}$, Packer L,

Parthasarathy S, Sies H, Traber MG. Vitamins $E$ and $C$ are safe across a broad range of intakes. Am J Clin Nutr, 2005;81:736-745. 